\title{
PENGARUH MOTIVASI BERPRESTASI DAN PERSEPSI SISWA TENTANG METODE MENGAJAR GURU TERHADAP PRESTASI BELAJAR SISWA SMK NEGERI 1 PENGASIH
}

\author{
Oleh \\ Arlin Nosa Sefrian Sari ${ }^{1}$ \\ Abdullah Taman ${ }^{2}$
}

\begin{abstract}
Abstrak
Penelitian ini bertujuan untuk mengetahui: (1) Pengaruh Motivasi Berprestasi terhadap Prestasi Belajar Akuntansi Keuangan; (2) Pengaruh Persepsi Siswa tentang Metode Mengajar Guru terhadap Prestasi Belajar Akuntansi Keuangan; (3) Pengaruh Motivasi Berprestasi dan Pengaruh Persepsi Siswa tentang Metode Mengajar Guru secara bersama-sama terhadap Prestasi Belajar Akuntansi Keuangan siswa Kelas XI Kompetensi Keahlian Akuntansi SMK Negeri 1 Pengasih Tahun Ajaran 2012/2013 yang berjumlah 64 siswa. Teknik pengumpulan data menggunakan angket untuk variabel Motivasi Berprestasi dan Persepsi Siswa tentang Metode Mengajar Guru, sedangkan dokumentasi untuk variabel Prestasi Belajar Akuntansi Keuangan. Kedua data tersebut telah diuji validitas dan reliabilitasnya. Uji prasyarat analisis menggunakan uji linearitas, dan uji multikolinearitas. Pengujian hipotesis pertama dan kedua menggunakan regresi sederhana, sedangkan pengujian hipotesis ketiga menggunakan regresi berganda. Hasil penelitian menunjukkan bahwa: (1)terdapat pengaruh positif dan signifikan Motivasi Berprestasi terhadap Prestasi Belajar Akuntansi Keuangan dibuktikan $\mathrm{r}_{\mathrm{x} 1 \mathrm{y}} 0,634, \mathrm{r}_{\mathrm{x} 1 \mathrm{y}}^{2} 0,401$ dan $\mathrm{t}_{\text {hitung }} 6,447>\mathrm{t}_{\text {tabel }} 1,671$; (2)terdapat pengaruh positif dan signifikan Persepsi Siswa tentang Metode Mengajar Guru terhadap Prestasi Belajar Akuntansi Keuangan ditunjukkan, dibuktikan $\mathrm{r}_{\mathrm{x} 2 \mathrm{y}} 0,696, \mathrm{r}_{\mathrm{x} 2 \mathrm{y}}^{2} 0,484$ dan $\mathrm{t}_{\text {hitung }} 7,632>\mathrm{t}_{\text {tabel }} 1,671$; (3) terdapat pengaruh positif dan signifikan Motivasi Berprestasi dan Pengaruh Persepsi Siswa tentang Metode Mengajar Guru secara bersama-sama terhadap Prestasi Belajar Akuntansi Keuangan, dibuktikan $R_{y(1,2)}=$ $0,759, \mathrm{R}_{\mathrm{y}(1,2)}^{2}=0,576$ dan $\mathrm{F}_{\text {hitung }} 41,403>\mathrm{F}_{\text {tabel }} 3,140$. Penelitian ini menunjukkan besarnya sumbangan relatif dari variabel Motivasi Berprestasi sebesar 39,73\%, variabel Persepsi Siswa tentang Metode Mengajar Guru 60,27\%, sedangkan sumbangan efektif variabel Motivasi Berprestasi sebesar 22,89\%, variabel Persepsi Siswa tentang Metode Mengajar Guru sebesar 34,71\%.
\end{abstract}

Kata Kunci : Motivasi Berprestasi, Metode Mengajar, Prestasi Belajar

\begin{abstract}
This research was aimed to know: 1) The Influence of Achievement Motivation to Learning Achievement of Financial Accounting; 2) The Influence of Student's Perception about Teacher's Teaching Method to Learning Achievement
\end{abstract}

\footnotetext{
${ }^{1}$ Alumni Prodi Pendidikan Akuntansi Fakultas Ekonomi Universitas Negeri Yogyakarta

${ }^{2}$ Staf Pengajar Jurusan P. Akuntansi Fakultas Ekononi Universitas Negeri Yogyakarta
} 
of Financial Accounting; 3) The Influence of Achievement Motivation in association with Student's Perception about Teacher's Teaching Method to Learning Achievement of Financial Accounting of Grade XI Accounting Skills Competency SMK N 1 Pengasih in Academic Year 2012/2013that consist of 64 students. The data gathering technique of this research was using questionnaire for Achievement Motivation and Student's Perception about Teacher's Teaching Method variable, and documentation for Learning Achievement of Financial Accounting variable. The validity and the reliability of both data were tested. The analyses of prerequisite test of this research were linearity testand multicolinearity test. The first and the second hypothesis examining employed simple regression, while the third hypothesis examining employed doubled regression. The result of the research showed that: (1) there was positive and significant influence of Achievement Motivation to Learning Achievement of Financial Accounting, it was proved by $r_{x x y} 0,634, r_{x l y}^{2} 0,401, t_{\text {count }}(6,447)>$ $t_{\text {table }}(1,671)$; (2) there was positive and significant influence of Perception to Learning Achievement of Financial Accounting, it was proved by $r_{x 2 y} r_{x 2 y} 0,696$, $r_{x 2 y}^{2} 0,484, t_{c o u n t}(7,632)>t_{\text {table }}(1,671)$; (3) there was positive and significant influence of Achievement Motivation in association with Perception to Learning Achievement of Financial Accounting, it was proved by $R_{y(1,2)}=0,759, R_{y(1,2)}^{2}=$ $0,576, \quad F_{\text {count }}(41,403)>F_{\text {table }}(3,140)$. This research showed the relative contribution of Achievement Motivation variable was 39,73\%, Perception variable was60,27\%, and effective contribution of Achievement Motivationvariable was 22,89\%, Perceptioon variable was $34,71 \%$.

Keywords: Achievement Motivation, Teaching Method, Learning Achievement

\section{A. Pendahuluan}

Pendidikan memegang peranan yang sangat penting dalam mewujudkan tujuan pembangunan nasional. Sekolah merupakan lembaga pendidikan formal yang memiliki peran dan tanggung jawab yang sangat penting dalam menghasilkan sumber daya manusia yang berkualitas.Salah satu tujuan pendidikan formal di sekolah adalah meningkatkan prestasi belajar.

Prestasi belajar mencerminkan sampai seberapa jauh siswa menangkap dan memahami materi pembelajaran.Prestasi Belajar Akuntansi Keuangan merupakan hasil yang diperoleh siswa setelah mempelajari mata pelajaran Akuntansi Keuangan yang berupa penguasaan pengetahuan, sikap dan keterampilan yang dapat diukur dengan tes dimana hasilnya dalam bentuk angka atau simbol. Dasar untuk mengukur optimal tidaknya prestasi belajar siswa yaitu pada Kriteria Ketuntasan Minimal (KKM) masing-masing mata pelajaran. Hasil observasi awal mengenai Prestasi Belajar Akuntansi Keuangan dari data hasil Ulangan Harianmenunjukkan bahwa sebanyak 20 siswa atau $31,25 \%$ dari jumlah 64 siswa mendapat nilai di bawah Kriteria Ketuntasan Minimal (KKM) sebesar 75.

Upaya untuk mencapai Prestasi Belajar Akuntansi Keuangan yang memuaskan tidak terlepas dari berbagai faktor yang mempengaruhinya. Faktor internal yang mempengaruhi prestasi belajar salah satunya adalah Motivasi Berprestasi. Menurut Djaali (2012: 110), "Motivasi berprestasi 
merupakan salah satu faktor yang ikut menentukan keberhasilan dalam belajar". Motivasi Berprestasi dapat mempengaruhi aktivitas belajar siswa sehingga pada akhirnya merupakan suatu usaha untuk mencapai Prestasi Belajar Akuntansi Keuangan secara optimal. Motivasi Berprestasi dapat mendorong siswa untuk lebih meningkatkan dan mempertahankan prestasi belajar Akuntansi Keuangan. Siswa yang memiliki Motivasi Berprestasi tinggi akan menunjukkan nilai yang lebih tinggi dalam prestasi belajarnya dibandingkan dengan siswa yang memiliki Motivasi Berprestasi rendah.

Selain Motivasi Berprestasi, faktor lain yang mempengaruhi Prestasi Belajar Akuntansi Keuangan siswa adalah Persepsi Siswa tentang Metode Mengajar Guru. Persepsi Siswa tentang Metode Mengajar Guru adalah suatu proses penafsiran, penilaian dan pemaknaan siswa mengenai bagaimana cara guru Akuntansi menyampaikan materi dalam proses pembelajaran. Guru memiliki metode yang berbeda-beda dalam mengajar di kelas, khususnya guru mata pelajaran Akuntansi Keuangan. Siswa mempunyai persepsi yang berbeda-beda mengenai metode mengajar guru. Ada siswa yang memiliki persepsi positif (baik) dan ada pula siswa yang memiliki persepsi negatif (buruk) terhadap metode mengajar guru.

Berdasarkan uraian di atas, menjadikan dasar bagi peneliti untuk meneliti masalah ini ke dalam skripsi dengan judul "Pengaruh Motivasi Berprestasi dan Persepsi Siswa tentang Metode mengajar Guru terhadap Prestasi Belajar Akuntansi Keuangan Siswa Kelas XI Kompetensi Keahlian Akuntansi SMK Negeri 1 Pengasih Tahun Ajaran 2012/2013".

\section{Pengertian Prestasi Belajar Akuntansi Keuangan}

Muhibbin Syah (2008: 141) menjelaskan bahwa prestasi merupakan tingkat keberhasilan siswa mencapai tujuan yang telah ditetapkan dalam sebuah program, sedangkan "Belajar ialah suatu proses usaha yang dilakukan seseorang untuk memperoleh suatu perubahan tingkah laku yang baru secara keseluruhan, sebagai hasil pengalamannya sendiri dalam interaksidengan lingkungannya" (Slameto, 2010: 2).

Prestasi belajar adalah nilai-nilai yang merupakan perumusan terakhir yang diberikan oleh guru terkait mengenai kemajuan atau prestasi belajar siswa selama masa tertentu (Sumadi Suryabrata, 2006: 297). Pendapat lain dikemukakan oleh Sutratinah Tirtonegoro (2001: 43), "Prestasi belajar adalah penilaian hasil usaha kegiatan belajar yang dinyatakan dalam bentuk simbol, angka, huruf maupun kalimat yang dapa mencerminkan hasil yang sudah dicapai oleh setiap anak dalam periode tertentu".

Berdasarkan berbagai macam teori yang diuraikan di atas, maka dapat disimpulkan Prestasi Belajar Akuntansi Keuangan adalah adalah hasil yang diperoleh siswa setelah mempelajari mata pelajaran Akuntansi Keuangan yang berupa penguasaan pengetahuan, sikap, dan keterampilan yang dapat diukur dengan tes dimana hasilnya dalam bentuk angka atau simbol.

\section{Pengertian Motivasi Berprestasi}

Pengertian motivasi menurut Ngalim Puwanto (2007: 71) "Motivasi adalah suatu usaha yang disadari untuk menggerakkan, 
mengarahkan, dan menjaga tingkah laku seseorang agar ia terdorong untuk bertindak melakukan sesuatu sehingga mencapai hasil atau tujuan tertentu".

Menurut Nana Syaodih Sukmadinata (2005: 70), "Motivasi berprestasi adalah motivasi untuk berkompetisi baik dengan dirinya atau dengan orang lain dalam mencapai prestasi yang tertinggi". Pendapat lain dikemukakan oleh Djaali (2012: 110), "Motivasi berprestasi merupakan salah satu faktor yang ikut menentukan keberhasilan dalam belajar". Besar kecilnya pengaruh tersebut tergantung pada intensitasnya.

Jadi, dapat disimpulkan bahwa Motivasi Berprestasi merupakan dorongan yang muncul dari dalam maupun dari luar diri individu yang diwujudkan dalam usaha yang dilakukan siswa dalam kegiatan belajar mengajar untuk mencapai prestasi setinggi-tingginya. Kebanyakan siswa pasti menginginkan mendapatkan prestasi yang baik. Pada umumnya siswa akan mendekati hal-hal yang menyenangkan, oleh karena itu guru harus bisa menimbulkan suasana yang menyenangkan agar siswa selalu berkeinginan untuk belajar.

\section{Pengertian Persepsi Siswa tentang Metode Mengajar Guru}

Pengertian persepsi menurut Bimo Walgito (2004: 87) yaitu "Persepsi merupakan suatu proses yang didahului proses penginderaan, yaitu merupakan proses diterimanya stimulus oleh individu melalui alat indera atau juga disebut proses sensoris".

Menurut Nana Sudjana (2005: 76), "Metode mengajar ialah cara yang dipergunakan guru dalam mengadakan hubungan dengan siswa pada saat berlangsungnya pengajaran". Pendapat lain dikemukakan oleh Muhibbin Syah (2008: 201), "Metode mengajar adalah cara yang berisi prosedur baku untuk melaksanakan kegiatan pendidikan, khususnya kegiatan penyajian materi pelajaran kepada siswa".

Dapat disimpulkan bahwa Persepsi Siswa tentang Metode Mengajar Guru adalah suatu proses penafsiran, penilaian dan pemaknaansiswa mengenai bagaimana cara guru akuntansi menyampaikan materi dalam proses pembelajaran.

\section{B. Metode Penelitian}

\section{Tempat dan Waktu Penelitian}

Penelitian ini dilaksanakan pada kelas XI Kompetensi Keahlian Akuntansi SMK Negeri 1 Pengasih yang beralamat di Jalan Kawijo 11, Pengasih, Pengasih, Kulon Progo 55652. Penelitian ini dilaksanakan pada bulan Desember 2012 sampai Januari 2013.

\section{Desain Penelitian}

Penelitian ini adalah penelitian yang bersifat ex-post facto. Menurut Suharsimi (2010: 17), penelitian ex-post facto adalah penelitian tentang variabel yang kejadiannya sudah terjadi sebelum penelitian dilaksanakan.Penelitian ini menggunakan pendekatan kuantitatif.Ditinjau dari tujuannya, penelitian ini merupakan penelitian kausal komparatif. Menurut Sukardi (2005: 171), penelitian kausal komparatif melibatkan kegiatan peneliti yang diawali dari mengidentifikasi pengaruh variabel 
satu terhadap variabel lainnya, kemudian dia berusaha mencari kemungkinan variabel penyebabnya.

\section{Populasi Penelitian}

Menurut Suharsimi (2010: 173), "Populasi adalah keseluruhan subjek penelitian". Populasi dapat berupa kumpulan kelompok yang anggotanya orang, kejadian, atau benda. Sedangkan menurut Sugiyono, "Populasi adalah wilayah generalisasi yang terdiri atas: objek/subjek yang mempunyai kualitas dan karakteristik tertentu yang ditetapkan oleh peneliti untuk dipelajari dan kemudian ditarik kesimpulannya" (Sugiyono, 2009: 117).Populasi dari penelitian ini adalah seluruh siswa kelas XI Kompetensi Keahlian Akuntansi SMK N 1 Pengasih tahun ajaran 2012/2013 yang berjumlah 64 siswa.

\section{Teknik Pengumpulan Data}

a. Metode Kuesioner

Menurut Suharsimi (2010: 194), "Kuesioner adalah sejumlah pertanyaan tertulis yang digunakan untuk memperoleh informasi dari responden dalam arti laporan tentang pribadinya, atau hal-hal yang ia ketahui". Dilihat dari cara menjawabnya, penelitian ini menggunakan jenis kuesioner tertutup dimana telah disediakan alternatif jawabannya sehingga responden tinggal memilih. Metode ini digunakan untuk memperoleh data mengenai Motivasi Berprestasi dan Persepsi Siswa tentang Metode Mengajar Guru.

b. Metode Dokumentasi

Dokumentasi digunakan untuk memperoleh data mengenai Prestasi Belajar Akuntansi Keuangan siswa. Data ini diperoleh dari hasil perolehan rata-rata nilai Ulangan Harian (UH) dan Ujian Akhir Semester (UAS) pada semester gasal yang dicapai siswa kelas XI Program Keahlian Akuntansi SMK Negeri 1 Pengasih tahun ajaran 2012/2013.

\section{Instrumen Penelitian}

Kisi-kisi instrumen Motivasi Berprestasi meliputi menyukai tugas yang menuntut tanggung jawab pribadi, memiliki tujuan yang realistis dan menantang, bersedia menerima perubahan dan umpan balik, senang bekerja mandiri, senang bersaing untuk mengungguli orang lain dan keinginan/dorongan berprestasi. Sedangkan kisi-kisi Persepsi Siswa tentang Metode Mengajar Guru meliputi metode mengajar sesuai dengan pengelolaan siswa di kelas, metode mengajar sesuai dengan tujuan pembelajaran, metode mengajar sesuai dengan situasi dan waktu pembelajaran, metode mengajar sesuai dengan fasilitas yang tersedia dan metode mengajar sesuai dengan kemampuan guru

\section{Uji Coba Instrumen}

Uji coba instrumen dilakukan pada 30 siswa kelas XI Kompetensi Keahlian Akuntansi SMK Negeri 1 Depok. SMK Negeri 1 Depokdipilih sebagai tempat uji coba karena mempunyai karakteristik yang sama dengan SMK Negeri 1 Pengasih yaitu sama-sama Sekolah Menengah Kejuruan (SMK) Negeri serta letak sekolah yang berada di wilayah Kota Yogyakarta.

\section{a. Uji Validitas}




$$
r_{x y}=\frac{N \sum X Y-\left(\sum X\right)\left(\sum Y\right)}{\sqrt{\left\{N \sum X^{2}-\left(\sum X\right)^{2}\right\}\left\{N \sum Y^{2}-\left(\sum Y\right)^{2}\right\}}}
$$

(Suharsimi, 2010: 317)

Hasil uji validitas dirangkum dalam tabel berikut:

\begin{tabular}{|c|c|c|c|c|}
\hline Variabel & $\begin{array}{c}\text { Jumlah } \\
\text { butir } \\
\text { semula }\end{array}$ & $\begin{array}{c}\text { Jumlah } \\
\text { butir } \\
\text { gugur }\end{array}$ & $\begin{array}{c}\text { Nomor } \\
\text { butir } \\
\text { gugur }\end{array}$ & $\begin{array}{c}\text { Jumlah } \\
\text { butir } \\
\text { valid }\end{array}$ \\
\hline Motivasi Berprestasi $\left(\mathrm{X}_{1}\right)$ & 25 & 3 & $2,9,18$ & 22 \\
\hline $\begin{array}{l}\text { Persepsi Siswa tentang } \\
\text { Metode Mengajar Guru }\left(\mathrm{X}_{2}\right)\end{array}$ & 20 & 2 & 4,15 & 18 \\
\hline \multicolumn{1}{|c|}{ Jumlah } & 45 & 5 & 5 & 40 \\
\hline
\end{tabular}

b. Uji Reliabilitas

Sumber: Data Primer yang diolah

Cara menghitung reliabilitas menggunakan rumus Cronbach Alpha, yaitu:

$r_{11}=\left[\frac{k}{(k-1)}\right]\left[1-\frac{\sum \sigma_{\mathrm{b}}^{2}}{\sigma_{\mathrm{t}}^{2}}\right]$

(Suharsimi, 2010: 239)

Hasil uji reliabiltas dirangkum dalam tabel berikut:

\begin{tabular}{|l|c|c|}
\hline \multicolumn{1}{|c|}{ Variabel } & $\begin{array}{c}\text { Koefisien } \\
\text { Cronbach Alpha }\end{array}$ & Interpretasi \\
\hline Motivasi Berprestasi $\left(\mathrm{X}_{1}\right)$ & 0,828 & Sangat Tinggi \\
\hline $\begin{array}{l}\text { Persepsi Siswa tentang } \\
\text { Metode Mengajar Guru } \\
\left(\mathrm{X}_{2}\right)\end{array}$ & 0,852 & Sangat Tinggi \\
\hline
\end{tabular}

Sumber: Data Primer yang diolah

\section{Teknik Analisis Data}

\section{a. Deskripsi Data}

Data yang diperoleh dari lapangan, kemudian disajikan dalam bentuk deskipsi data dari masing-masing variabel. Analisis deskripsi data yang dimaksud meliputi peyajian Mean (M), Median (Me), Modus (Mo), Standar Deviasi (SD), Tabel Distribusi Frekuensi, Histogram, Diagram (Piechart) dan Tabel Kategori Kecenderungan masing-masing variabel.

b. Uji Prasyarat Analisis

\section{1) Uji Linearitas}

Uji ini digunakan untuk mengatahui apakah antara variabel bebas dengan variabel terikat mempunyai hubungan linear atau tidak.

$$
F_{\text {reg }}=\frac{R K_{\text {reg }}}{R K_{\text {res }}}
$$

(Sutrisno Hadi, 2004: 13) 
2) Uji Multikolinearitas

Uji multikolinearitas digunakan untuk mengetahui terjadi tidaknya multikolinearitas antara variabel bebas yang satu dengan variabel bebas yang lain.

$$
r_{x y}=\frac{N \sum \mathrm{XY}-\left(\sum \mathrm{X}\right)\left(\sum \mathrm{Y}\right)}{\sqrt{\left\{\mathrm{N} \sum \mathrm{X}^{2}-\left(\sum \mathrm{X}\right)^{2}\right\}\left\{\mathrm{N} \sum \mathrm{Y}^{2}-\left(\sum \mathrm{Y}\right)^{2}\right\}}}
$$

(Suharsimi, 2010: 317)

c. Uji Hipotesis

1) Analisis Regresi Sederhana

Analisis ini digunakan untuk mengetahui pengaruh antara Motivasi Berprestasi terhadapa Prestasi Belajar Akuntansi Keuangan (Hipotesis 1), dan Pengaruh Persepsi Siswa tentang Metode Mengajar Guru terhadap Prestasi Belajar Akuntansi Keuangan. (Hipotesis 2).

2) Analisis Regresi Berganda

Analisis ini digunakan untuk menguji pengaruh Motivasi Berprestasi dan Persepsi Siswa tentang Metode Mengajar Guruterhadap Prestasi Belajar Akuntansi Keuangan (Hipotesis 3).

\section{d. Sumbangan Relatif dan Sumbangan Efektif}

\section{1) Sumbangan Relatif (SR)}

Sumbangan relatif adalah persentase perbandingan yang diberikan oleh suatu variabel bebas kepada variabel terikat dengan variabel-variabel bebas yang lain. Sumbangan relatif menunjukkan seberapa besarnya sumbangan secara relatif setiap prediktor terhadap kriterium untuk keperluan prediksi.

$$
\begin{aligned}
& \text { Prediktor } X_{1}=S R \%=\frac{a_{1} \sum x_{1} y}{J K_{\text {reg }}} \times 100 \% \\
& \text { Prediktor } X_{2}=S R \%=\frac{a_{2} \sum x_{2} y}{J K_{\text {reg }}} \times 100 \%
\end{aligned}
$$

\section{2) Sumbangan Efektif (SE)}

(Sutrisno Hadi, 2004: 37)

Sumbangan efektif adalah sumbangan prediktor yang dihitung dari keseluruhan efektifitas regresi yang dibuat sumbangan efektif regresi. Sumbangan efektif digunakan untuk mengetahui besarnya sumbangan secara efektif setiap prediktor terhadap kriterium dengan tetap memperhitungkan variabel bebas lain yang tidak diteliti.

Prediktor $X_{1}=S E \% X_{1}=S R \% X_{1} \times R^{2}$

Prediktor $X_{2}=S E \% X_{2}=S R \% X_{2} \times R^{2}$

(Sutrisno Hadi, 2004: 39)

\section{Hasil Penelitian dan Pembahasan}

1. Deskripsi Data

a. Variabel Prestasi Belajar Akuntansi Keuangan 
Hasil analisis data menunjukkan bahwa untuk variabel Prestasi Belajar Akuntansi Keuangan (Y) diketahui bahwa skor tertinggi siswa yang diperoleh siswa adalah 93 dan skor terendah yang diperoleh siswa adalah 63. Setelah dianalisis dengan menggunakan SPSS Statistics 20.0 For Windowsdiperoleh Mean (M) sebesar 79,5; Median (Me) sebesar 79; Modus (Mo) sebesar 73; dan Standar Deviasi (SD) sebesar 7,149.

Jumlah kelas interval dihitung dengan menggunakan rumus Strugess Rule yaitu $1+3,3 \log \mathrm{n}=1+3,3 \log 64=6,960393914$ dibulatkan menjadi 7. Rentang Data (range) $=$ nilai tertinggi - nilai terendah $=93-63=30$. Panjang Kelas Interval $=$ Rentang Data/Jumlah Panjang Kelas Interval $=30 / 7=4,285714286$ dibulatkan menjadi 5. Frekuensi kecenderungan Prestasi Belajar Akuntansi Keuangan kategori belum tuntas sebanyak 18 siswa $(28,125 \%)$, sedangkan kategori tuntas sebanyak 46 siswa $(71,875 \%)$.

\section{b. Variabel Motivasi Berprestasi}

Data Motivasi Berprestasi diperoleh dari lembar kuesioner yang terdiri dari 22 butir pernyataan dengan menggunakanskala Likert yang terdiri dari empat alternatif jawaban, dimana 4 untuk skor tertinggi dan 1 untuk skor terendah. Dari 22 butir pernyataan yang ada dengan jumlah responden 64 siswa, menunjukkan bahwa variabel Motivasi Berprestasi diperoleh skor tertinggi sebesar 77 dari skor tertinggi yang mungkin dicapai sebesar $(4 \times 22)=88$ dan skor terendah sebesar 53 dari skor terendah yang mungkin dicapai sebesar $(1 \times 22)=22$. Hasil analisis dengan menggunakan program SPSS Statistics 20.0 For Windows menunjukkan Mean (M) sebesar 65,77; Median (Me) 65; Modus (Mo) sebesar 65; dan Standar Deviasi (SD) 4,743 .

Untuk mengetahui jumlah kelas interval digunakan rumus Strugess Rule, yaitu jumlah kelas interval $=1+3,3 \log \mathrm{n}$, maka dapat diketahui jumlah kelas interval $=1+3,3 \log 64$ sebesar6, 960393914dibulatkan menjadi7. Rentang data sebesar $77-53=24$. Dengan diketahuinya rentang data maka dapat diperoleh panjang kelas interval masing-masing kelompok yaitu $24 / 7=3,428571429$ dibulatkan menjadi 4. Frekuensi kecenderungan Motivasi Berprestasi kategori tinggi sebanyak 27 siswa $(42,1875 \%)$, kategori cukup sebanyak 37 siswa $(57,8125 \%)$ dan kategori rendah sebanyak 0 siswa $(0 \%)$.

\section{c. Variabel Persepsi Siswa tentang Metode Mengajar Guru}

Data Persepsi Siswa tentang Metode Mengajar Gurudiperoleh dari lembar kuesioner yang terdiri dari 18 butir pernyataan dengan menggunakan skala Likert yang terdiri dari empat alternatif jawaban, dimana 4 untuk skor tertinggi dan 1 untuk skor terendah. Dari 18 butir pernyataan yang ada dengan jumlah responden 64 siswa, menunjukkan bahwa variabel Persepsi Siswa tentang Metode Mengajar Guru diperoleh skor tertinggi sebesar 61 dari skor tertinggi 
yang mungkin dicapai sebesar $(4 \times 18)=72$ dan skor terendah sebesar 37 dari skor terendah yang mungkin dicapai sebesar $(1 \times 18)=18$. Hasil analisis dengan menggunakan program SPSS Statistics 20.0 For Windows menunjukkan Mean (M) sebesar 51,02;Median (Me) sebesar 52; Modus (Mo) sebesar 52; dan Standar Deviasi (SD) sebesar 5,728.

Untuk mengetahui jumlah kelas interval digunakan rumus Strugess Rule, yaitu jumlah kelas interval $=1+3,3 \log \mathrm{n}$, maka dapat diketahui jumlah kelas interval $=1+3,3 \log 64$ sebesar6, 960393914dibulatkan menjadi7. Rentang data sebesar $77-53=24$. Dengan diketahuinya rentang data maka dapat diperoleh panjang kelas interval masing-masing kelompok yaitu 24/7 = 3,428571429 dibulatkan menjadi 4. Frekuensi kecenderunganPersepsi Siswa tentang Metode Mengajar Gurukategori tinggi sebanyak 22siswa $(34,375 \%)$, kategori cukup sebanyak 42 siswa $(65,625 \%)$ dan kategori rendah sebanyak 0 siswa $(0 \%)$.

\section{Uji Prasyarat Analisis}

\section{a. Uji Linearitas}

Uji linieritas digunakan untuk mengetahui apakah masingmasing variabel bebas (X) mempunyai hubungan linier atau tidak dengan variabel terikat (Y). Linier atau tidaknya data variabel bebas dengan variabel terikat dapat diketahui dengan membandingkan $F_{\text {hitung }}$ dengan $\mathrm{F}_{\text {tabel }}$ dengan kriteria $\mathrm{F}_{\text {hitung }}<\mathrm{F}_{\text {tabel }}$ pada taraf signifikansi 5\% dikatakan linier.

Tabel Ringkasan Hasil Uji Linearitas

\begin{tabular}{|c|c|c|c|c|c|c|}
\hline \multirow{2}{*}{ No } & \multicolumn{2}{|c|}{ Variabel } & \multirow{2}{*}{ Df } & \multirow{2}{*}{ F $_{\text {hitung }}$} & F $_{\text {tabel }}$ & \multirow{2}{*}{ Kesimpulan } \\
\cline { 2 - 5 } & Bebas & Terikat & & & & \\
\hline 1. & $\mathrm{X}_{1}$ & $\mathrm{Y}$ & $15: 47$ & 0,466 & 1,86 & Linear \\
\hline 2. & $\mathrm{X}_{2}$ & $\mathrm{Y}$ & $20: 42$ & 1,613 & 1,82 & Linear \\
\hline
\end{tabular}

\section{b. Uji Multikolinearitas}

Uji multikolinieritas dimaksudkan untuk mengetahui ada tidaknya korelasi yang tinggi antar variabel bebas dalam model regresi. Multikolinieritas tidak terjadi apabila korelasi antarvariabel bebas bernilai kurang dari 0,600. Apabila tidak terjadi multikolinieritas maka analisis dapat dilanjutkan. Tabel Ringkasan Hasil Uji Multikolinieritas

\begin{tabular}{|c|c|c|c|}
\hline Variabel & $\mathbf{X}_{\mathbf{1}}$ & $\mathbf{X}_{\mathbf{2}}$ & Kesimpulan \\
\cline { 1 - 3 } $\mathrm{X}_{1}$ & 1 & 0,546 & Tidak terjadi \\
\cline { 1 - 2 } $\mathrm{X}_{2}$ & 0,546 & 1 & multikolinieritas \\
\hline
\end{tabular}

\section{Pengujian Hipotesis}

\section{a. Uji Hipotesis Pertama}


Pengujian hipotesis pertama menggunakan analisis regresi sederhana yang diperoleh dengan perhitungan program SPSS Statistics 20.0 For Windows.

Tabel Ringkasan Hasil Analisis Regresi Linier Sederhana $\left(\mathrm{X}_{1}-\mathrm{Y}\right)$

\begin{tabular}{|c|c|c|c|c|c|c|c|c|}
\hline \multirow{2}{*}{ Variabel } & \multicolumn{3}{|c|}{ Harga $\mathbf{~}$} & \multicolumn{2}{c|}{ Harga t } & Koef. & Konst. & Keterangan \\
\cline { 2 - 8 } & $\mathbf{r}_{\text {hitung }}$ & $\mathbf{r}_{\text {tabel }}$ & $\mathbf{r}^{2}$ & $\mathbf{t}_{\text {hitung }}$ & $\mathbf{t}_{\text {tabel }}$ & & & \multirow{2}{*}{$\begin{array}{c}\text { Positif dan } \\
\text { signifikan }\end{array}$} \\
\hline
\end{tabular}

1) Koefisien korelasi (r)

Berdasarkan perhitungan dengan memanfaatkan program SPSS Statistics 20.0 For Windows, didapatkan harga $\mathrm{r}$ positif sebesar 0,634, artinya Motivasi Berprestasi memiliki pengaruh positif terhadap Prestasi Belajar Akuntansi Keuangan.

2) Koefisien determinasi $\left(\mathrm{r}^{2}\right)$

Koefisien determinasi $\left(\mathrm{r}^{2} \mathrm{x} 1 \mathrm{y}\right)$ sebesar 0,401 berarti Motivasi Berprestasi mampu mempengaruhi 40,1\% perubahan Prestasi Belajar Akuntansi Keuangan. Hal ini menunjukkan masih ada $59,9 \%$ faktor atau variabel lain yang mempengaruhi Prestasi Belajar Akuntansi Keuangan selain Motivasi Berprestasi.

3) Pengujian signifikansi dengan uji $t$

Pengujian signifikansi bertujuan untuk mengetahui signifikansi Motivasi Berprestasi $\left(\mathrm{X}_{1}\right)$ terhadap Prestasi Belajar Akuntansi Keuangan (Y). berdasarkan uji t diperoleh thitung sebesar 6,447, jika dibandingkan dengan $t_{\text {tabel }}$ sebesar 1,671 pada taraf signifikansi 5\% maka thitung lebih besar dari tabel yang berarti bahwa terdapat pengaruh yang signifikan Motivasi Beprestasi terhadap Prestasi Belajar Akuntansi Keuangan.

4) Persamaan garis regresi

Besarnya harga koefisien Motivasi Berprestasi $\left(\mathrm{X}_{1}\right)$ sebesar 0,955 dan bilangan konstanta sebesar 16,703. Berdasarkan angka-angka tersebut, maka dapat disusun persamaan regresi yaitu $\mathrm{Y}=0,955$ $\mathrm{X}_{1}+16,703$.

\section{b. Uji Hipotesis Kedua}

Pengujian hipotesis pertama menggunakan analisis regresi sederhana yang diperoleh dengan perhitungan program SPSS Statistics 20.0 For Windows.

Tabel Ringkasan Hasil Analisis Regresi Linier Sederhana $\left(\mathrm{X}_{2}-\mathrm{Y}\right)$

\begin{tabular}{|c|c|c|c|c|c|c|c|c|}
\hline \multirow{2}{*}{ Variabel } & \multicolumn{3}{|c|}{ Harga $\mathbf{r}$} & \multicolumn{2}{c|}{ Harga t } & Koef. & Konst. & \multirow{2}{*}{ Keterangan } \\
\cline { 2 - 9 } & $\mathbf{r}_{\text {hitung }}$ & $\mathbf{r}_{\text {tabel }}$ & $\mathbf{r}^{2}$ & $\mathbf{t}_{\text {hitung }}$ & $\mathbf{t}_{\text {tabel }}$ & & & \multirow{2}{*}{$\begin{array}{c}\text { Positif dan } \\
\text { signifikan }\end{array}$} \\
\hline $\mathrm{X}_{2}-\mathrm{Y}$ & 0,696 & 0,244 & 0,484 & 7,632 & 1,671 & 0,869 & 35,185 & \\
\hline
\end{tabular}

1) Koefisien korelasi (r)

Berdasarkan perhitungan dengan memanfaatkan program SPSS Statistics 20.0 For Windows, didapatkan harga $\mathrm{r}$ positif sebesar 0,696 artinya Persepsi Siswa tentang Metode Mengajar Gurumemiliki pengaruh positif terhadap Prestasi Belajar Akuntansi Keuangan. 
2) Koefisien determinasi $\left(\mathrm{r}^{2}\right)$

Koefisien determinasi $\left(\mathrm{r}^{2} \times 1 \mathrm{y}\right)$ sebesar 0,484 berarti Motivasi Berprestasi mampu mempengaruhi $48,4 \%$ perubahan Prestasi Belajar Akuntansi Keuangan. Hal ini menunjukkan masih ada $51,6 \%$ faktor atau variabel lain yang mempengaruhi Prestasi Belajar Akuntansi Keuangan selain Persepsi Siswa tentang Metode Mengajar Guru.

3) Pengujian signifikansi dengan uji t

Pengujian signifikansi bertujuan untuk mengetahui signifikansi Persepsi Siswa tentang Metode Mengajar Guru $\left(\mathrm{X}_{2}\right)$ terhadap Prestasi Belajar Akuntansi Keuangan (Y). Berdasarkan uji t diperoleh thitung sebesar 7,632, jika dibandingkan dengan tabel sebesar 1,671 pada taraf signifikansi 5\% maka thitung lebih besar dari tabel yang berarti bahwa terdapat pengaruh yang signifikan Persepsi Siswa tentang Metode Mengajar Guru terhadap Prestasi Belajar Akuntansi Keuangan.

4) Persamaan garis regresi

Besarnya harga koefisien Persepsi Siswa tentang Metode Mengajar Guru $\left(\mathrm{X}_{2}\right)$ sebesar 0,869 dan bilangan konstanta sebesar 35,185. Berdasarkan angka-angka tersebut, maka dapat disusun persamaan regresi yaitu $Y=0,869 \mathrm{X}_{2}+35,185$.

\section{c. Uji Hipotesis Ketiga}

Pengujian hipotesis ketiga menggunakan analisis regresi ganda yang diperoleh dengan perhitungan program SPSS Statistics 20.0 For Windows.

Tabel Ringkasan Hasil Analisis Regresi Ganda

\begin{tabular}{|c|c|c|c|c|c|c|c|}
\hline \multirow{2}{*}{ Variabel } & \multirow{2}{*}{ Koef. } & \multirow{2}{*}{ Konst. } & \multicolumn{2}{|c|}{$\begin{array}{c}\text { Harga R dan } \\
\mathbf{R}^{\mathbf{2}}\end{array}$} & \multicolumn{2}{|c|}{ Harga t } & \multirow{2}{*}{ Keterangan } \\
\cline { 4 - 7 } & & & $\mathbf{R}_{\mathbf{y}(\mathbf{1}, \mathbf{2})}$ & $\mathbf{R}_{\mathbf{y}(\mathbf{1}, \mathbf{2})}$ & $\mathbf{F}_{\text {hitung }}$ & $\mathbf{F}_{\text {tabel }}$ & \\
\hline $\mathrm{X}_{1}$ & 0,544 & \multirow{2}{*}{11,957} & 0,759 & 0,576 & 41,403 & 3,15 & $\begin{array}{c}\text { Positif dan } \\
\text { signifikan }\end{array}$ \\
\hline $\mathrm{X}_{2}$ & 0,622 & & & & &
\end{tabular}

1) Koefisien korelasi (R)

Berdasarkan perhitungan diperoleh hasil $\mathrm{R}_{\mathrm{y}(1,2)}$ sebesar 0,759, artinya Motivasi Berprestasi dan Persepsi Siswa tentang Metode Mengajar Gurusecara bersama-sama memiliki pengaruh positif terhadap Prestasi Belajar Akuntansi Keuangan.

2) Koefisien determinasi $\left(R^{2}\right)$

Koefisien determinasi $\left(\mathrm{R}^{2}\right)$ sebesar 0,576, berarti bahwa Motivasi Berprestasi dan Persepsi Siswa tentang Metode Mengajar Gurusecara bersama-sama mampu mempengaruhi 57,6\% perubahan pada Prestasi Belajar Akuntansi Keuangan. Hal ini menunjukkan masih ada $42,4 \%$ faktor atau variabel lain yang mempengaruhi Prestasi Belajar Akuntansi Keuangan selain Motivasi Berprestasi dan Persepsi Siswa tentang Metode Mengajar Guru.

3) Pengujian signifikansi dengan uji $\mathrm{F}$ 
Selanjutnya, untuk mengetahui signifikansi pengaruh digunakan uji F. Setelah dilakukan uji F diperoleh $F_{\text {hitung }}$ sebesar 41,403 lebih besar dari $F_{\text {tabel }}$ pada taraf signifikansi 5\% sebesar 3,14, maka $\mathrm{F}_{\text {hitung }}$ lebih besar dari $\mathrm{F}_{\text {tabel. }}$ Hal ini menunjukkan bahwa terdapat pengaruh signifikan Motivasi Berprestasi dan Persepsi Siswa tentang Metode Mengajar Guru secara bersama-sama terhadap Prestasi Belajar Akuntansi Keuangan Siswa Kelas XI Kompetensi Keahlian Akuntansi SMK Negeri 1 Pengasih Tahun Ajaran 2012/2013.

4) Persamaan garis regresi

Besarnya harga koefisien prediktor Motivasi Berprestasi $\left(\mathrm{X}_{1}\right)$ adalah 0,544 dan Persepsi Siswa tentang Metode Mengajar Guru $\left(\mathrm{X}_{2}\right)$ adalah 0,622. Berdasarkan angka-angka tersebut dapat disusun persamaan garis regresi dua prediktor sebagai berikut yaitu $Y=0,544 X_{1}+0,622 X_{2}+11,957$.

Persamaan tersebut menunjukkan bahwa jika 1) Nilai koefisien $X_{1}$ sebesar 0,544 yang berarti apabila nilai Motivasi Berprestasi $\left(\mathrm{X}_{1}\right)$ meningkat 1 poin, nilai Persepsi Siswa tentang Metode Mengajar $\operatorname{Guru}\left(\mathrm{X}_{2}\right)$ tetap maka Prestasi Belajar Akuntansi Keuangan (Y) akan meningkat 0,544 poin; 2)Nilai koefisien $\mathrm{X}_{2}$ sebesar 0,622 yang berarti apabila nilai Persepsi Siswa tentang Metode Mengajar Guru $\left(\mathrm{X}_{2}\right)$ naik 1 poin, nilai Motivasi Berprestasi $\left(\mathrm{X}_{1}\right)$ tetap maka Prestasi Belajar Akuntansi Keuangan (Y) akan meningkat 0,622 poin.

\section{d. Sumbangan Relatif (SR) dan Sumbangan Efektif (SE)}

Berdasarkan hasil analisis regresi ganda, dapat diketahui besarnya Sumbangan Relatif (SR) dan Sumbangan Efektif (SE) masing-masing variabel bebas terhadap variabel terikat sebagai berikut:

Tabel Sumbangan Relatif dan Sumbangan Efektif

\begin{tabular}{|c|l|c|c|}
\hline \multirow{2}{*}{ No. } & \multicolumn{2}{|c|}{ Nama Variabel } & \multicolumn{2}{c|}{ Sumbangan } \\
\cline { 3 - 4 } & \multicolumn{1}{|c|}{ Relatif } & Efektif \\
\hline 1. & Motivasi Berprestasi $\left(\mathrm{X}_{1}\right)$ & $39,73 \%$ & $22,89 \%$ \\
\hline 2. & $\begin{array}{l}\text { Persepsi Siswa tentang } \\
\text { Metode Mengajar Guru }\left(\mathrm{X}_{2}\right)\end{array}$ & $60,27 \%$ & $34,71 \%$ \\
\hline & Total & $100 \%$ & $57,60 \%$ \\
\hline
\end{tabular}

\section{Pembahasan Hasil Penelitian}

\section{a. Pengaruh Motivasi Berprestasi terhadap Prestasi Belajar Akuntansi Keuangan}

Hasil penelitian ini menunjukkan bahwa terdapat pengaruh positif dan signifikan Motivasi Berprestasi $\left(\mathrm{X}_{1}\right)$ terhadap Prestasi Belajar Akuntansi Keuangan (Y). Dari hasil analisis dengan menggunakan regresi sederhana diperoleh harga koefisien korelasi $\left(\mathrm{r}_{\mathrm{x} 1 \mathrm{y}}\right)$ sebesar 0,634 lebih besar dari $\mathrm{r}_{\text {tabel }}$ dengan taraf kesalahan 5\% sebesar 0,244dan harga koefisien determinasi $\left(\mathrm{r}_{\mathrm{x} 1 \mathrm{y}}^{2}\right)$ sebesar 0,401 . Setelah dilakukan uji $\mathrm{t}$ diperoleh harga $t_{\text {hitung }}$ sebesar 6,447 dan $t_{\text {tabel }}$ 
pada taraf signifikansi 5\%sebesar 1,671. Hal ini menunjukkan bahwa $t_{\text {hitung }}$ lebih besar dari tabel, yang berarti pengaruh Motivasi Berprestasi terhadap Prestasi Belajar Akuntansi Keuangan adalah signifikan. Dengan demikian dapat disimpulkan bahwa Motivasi Berprestasi berpengaruh positif dan signifikan terhadapPrestasi Belajar Akuntansi Keuangan.

b. Pengaruh Persepsi Siswa tentang Metode Mengajar Guru terhadap Prestasi Belajar Akuntansi Keuangan

Hasil penelitian ini menunjukkan bahwa terdapat pengaruh positif dan signifikan Persepsi Siswa tentang Metode Mengajar Guru terhadap Prestasi Belajar Akuntansi Keuangan. Dari hasil analisis dengan menggunakan regresi sederhana (satu prediktor) diperoleh harga koefisien korelasi $\left(\mathrm{r}_{\mathrm{x} 2 \mathrm{y}}\right)$ sebesar 0,696 lebih besar dari $\mathrm{r}_{\text {tabel }}$ dengan taraf kesalahan 5\% sebesar 0,244dan harga koefisien determinasi $\left(\mathrm{r}^{2}\right)$ adalah 0,484 . Setelah dilakukan uji t diperoleh harga $t_{\text {hitung sebesar 7,632 dan }} t_{\text {tabel }}$ pada taraf signifikansi 5\% dan sebesar 1,671. Hal ini menunjukkan bahwa thitung lebih besar dari tabel, yang berarti pengaruh Motivasi Berprestasi terhadap Prestasi Belajar Akuntansi Keuangan adalah signifikan. Dengan demikian dapat disimpulkan bahwa Persepsi Siswa tentang Metode Mengajar Guru berpengaruh positif dan signifikan terhadapPrestasi Belajar Akuntansi Keuangan.

c. Pengaruh Minat Belajar dan Pemanfaatan Waktu Belajar Siswa di Luar Jam Pelajaran secara Bersama-sama terhadap Prestasi Belajar Akuntansi Keuangan

Hasil penelitian ini menunjukkan bahwa terdapat pengaruh positif dan signifikan Motivasi Berprestasi dan Persepsi Siswa tentang Metode Mengajar Guru secara bersama-sama terhadap Prestasi Belajar Akuntansi Keuangan. Dari hasil analisis dengan menggunakan regresi ganda diperoleh harga koefisien korelasi $\mathrm{R}_{\mathbf{y}(1,2)}$ sebesar 0,759 dan harga koefisien determinasi $\left(\mathrm{R}_{\mathrm{y}(1,2)}^{2}\right)$ sebesar 0,576 . Setelah dilakukan uji $\mathrm{F}$ diperoleh harga $\mathrm{F}_{\text {hitung }}$ sebesar 41,403 dan $\mathrm{F}_{\text {tabel }}$ dengan sebesar 3,140. Hal ini menunjukkan bahwa $F_{\text {hitung }}$ lebih besar dari $\mathrm{F}_{\text {tabel, }}$ sehingga dapat disimpulkan bahwa terdapat pengaruh positif dan signifikan Motivasi Berprestasi dan Persepsi Siswa tentang Metode Mengajar Gurusecara bersama-sama terhadap Prestasi Belajar Akuntansi Keuangan.Besarnya sumbangan Motivasi Berprestasi dan Persepsi Siswa tentang Metode Mengajar Guru secara bersama-sama terhadap Prestasi Belajar Akuntansi Keuangan ditunjukkan dengan hasil analisis regresi ganda yang ditemukan, besarnya sumbangan efektif sebesar $57,6 \%$, sedangkan $42,4 \%$ berasal dari variabel yang tidak diteliti dalam penelitian ini.

\section{Penutup}




\section{Kesimpulan}

Berdasarkan data yang diperoleh dari hasil analisis, maka kesimpulan yang dapat dikemukakan dalam penelitian ini adalah sebagai berikut:

a. Terdapat pengaruh positif dan signifikan Motivasi BerprestasiterhadapPrestasi Belajar Akuntansi Keuangan Siswa Kelas XI Kompetensi Keahlian Akuntansi SMK Negeri 1 Pengasih Tahun Ajaran 2012/2013. Hal ini ditunjukan dengan harga $r_{x 1 y}$ sebesar $0,634, r_{x 1 y}^{2}$ sebesar 0401, harga $t_{\text {hitung }}$ sebesar 6,447 lebih besar dari $t_{\text {tabel }}$ 1,671 pada taraf signifikansi 5\%.Hal ini menunjukkan bahwa semakin tinggi Motivasi Berprestasi maka akan semakin tinggi pula Prestasi Belajar Akuntansi Keuangan yang akan dicapai siswa.

b. Terdapat pengaruh positif dan signifikan Persepsi Siswa tentang Metode Mengajar Guru terhadapPrestasi Belajar Akuntansi Keuangan Siswa Kelas XI Kompetensi Keahalian Akuntansi SMK Negeri 1 Pengasih Tahun Ajaran 2012/2013. Hal ini ditunjukan dengan harga $r_{x 2 y}$ sebesar $0,696, r_{x 2 y}^{2}$ sebesar 0,484 , harga $t_{\text {hitung }}$ sebesar 7,632 lebih besar dari $t_{\text {tabel }}$ 1,671 pada taraf signifikansi $5 \%$. Hal ini menunjukkan bahwa semakin tinggi (positif) Persepsi Siswa tentang Metode Mengajar Guru maka akan semakin tinggi pula Prestasi Belajar Akuntansi Keuangan yang akan dicapai siswa

c. Terdapat pengaruh positif dan signifikan Motivasi Berprestasi danPersepsi Siswa tentang Metode Mengajar Guru secara bersamasama terhadapPrestasi Belajar Akuntansi Keuangan Siswa Kelas XI Kompetensi Keahlian Akuntansi SMK Negeri 1 Pengasih Tahun Ajaran 2012/2013. Hal ini ditunjukan dengan harga $\mathrm{R}_{\mathrm{y}(1,2)}$ sebesar $0,759, \mathrm{R}_{\mathrm{y}(1,2)}$ sebesar 0,576, harga $\mathrm{F}_{\text {hitung }}$ sebesar 41,403 lebih besar dari $\mathrm{F}_{\text {tabel }} 3,15$ pada taraf signifikansi 5\%. Hal ini menunjukkan bahwa semakin tinggi Motivasi Berprestasi siswa dan semakin tinggi(positif) Persepsi Siswa tentang Metode Mengajar Guru maka akan semakin tinggi pula Prestasi Belajar Akuntansi Keuangan yang akan dicapai siswa.

\section{Implikasi}

Berdasarkan hasil pembahasan penelitian dan kesimpulan yang diambil dalam penelitian ini maka dapat disajikan implikasi sebagai berikut:

a. Penelitian ini menunjukkan bahwa terdapat pengaruh positif dan signifikan Motivasi BerprestasiterhadapPrestasi Belajar Akuntansi Keuangan Siswa Kelas XI Kompetensi Keahlian Akuntansi SMK Negeri 1 Pengasih Tahun Ajaran 2012/2013. Hal ini menunjukkan bahwa semakin tinggi Motivasi Berprestasi maka Prestasi Belajar Akuntansi juga tinggi, sebaliknya jika Motivasi Berprestasi siswa rendah maka Prestasi Belajar Akuntansi Keuangan juga rendah.

b. Penelitian ini menunjukkan bahwa terdapat pengaruh positif dan signifikan Persepsi Siswa tentang Metode Mengajar Guru terhadapPrestasi Belajar Akuntansi Keuangan Siswa Kelas XI Kompetensi Keahalian Akuntansi SMK Negeri 1 Pengasih Tahun 
Ajaran 2012/2013. Hal ini menunjukan bahwa jikaPersepsi Siswa tentang Metode Mengajar Gurusemakin tinggi (positif)maka Prestasi Belajar Akuntansi akan meningkat, sebaliknya jika Persepsi Siswa tentang Metode Mengajar Guru siswa rendahmaka Prestasi Belajar Akuntansi Keuangan akan menurun.

c. Penelitian ini menunjukkan bahwa terdapat pengaruh positif dan signifikan Motivasi Berprestasi danPersepsi Siswa tentang Metode Mengajar Guru secara bersama-sama terhadapPrestasi Belajar Akuntansi Keuangan Siswa Kelas XI Kompetensi Keahlian Akuntansi SMK Negeri 1 Pengasih Tahun Ajaran 2012/2013. Hal ini dapat dijadikan sebagai salah satu acuan atau masukan untuk menciptakan kondisi yang baik untuk kedua faktor tersebut.

\section{Saran}

Berdasarkan hasil pembahasan, kesimpulan dan impilkasi tersebut maka dapat diberikan saran-saran sebagai berikut:

a. Bagi Siswa

Untuk meningkatkan Prestasi Belajar Akuntansi Keuangan, siswa harus mempunyai Motivasi Berprestasi yang tinggi serta Persepsi Siswa tentang Metode Mengajar Guru yang positif. Hal tersebut dapat dilakukan diantaranya dengan menumbuhkan Motivasi Berprestasidengan cara lebih giat belajar serta aktif di kelas. Selain itu siswa juga memperbaiki persepsinya tentang metode mengajar guru agar lebih semangat ketika proses belajar mengajar.

b. Bagi Guru

Guru diharapkan dapat melakukan upaya-upaya untuk meningkatkan Prestasi Belajar Akuntansi Keuangan dengan cara menggunakan metode mengajar yang lebih bervariasi dan media pembelajaran yang menarik sehingga membuat siswa semangat belajar karena siswa cenderung bosan dengan metode ceramah atau pemberian tugas. Selain itu, guru diharapkan ikut memberikan dorongan kepada siswa untuk meningkatkan Motivasi Berprestasi yang dimilikinya

c. Bagi Peneliti Lain

Penelitian ini memberikan informasi bahwa faktor Motivasi Berprestasi dan Persepsi Siswa tentang Metode Mengajar Gurusecara bersama-sama berpengaruh terhadap Prestasi Belajar Akuntansi Keuangan Siswa Kelas XI Kompetensi Keahlian Akuntansi SMK Negeri 1 Pengasih Tahun Ajaran 2012/2013. Sumbangan Efektif yang diberikan sebesar 57,6\%. Hasil tersebut menunjukkan bahwa Prestasi Belajar Akuntansi tidak hanya dipengaruhi dua variabel yaitu Motivasi Berprestasi dan Persepsi Siswa tentang Metode Mengajar Guru namun masih banyak dipengaruhi oleh variabel-variabel lain yang tidak diteliti pada penelitian ini. Oleh karena itu dimungkinkan untuk peneliti lain untuk melakukan penelitian tentang variabelvariabel lain yang berkaitan dengan Prestasi Belajar Akuntansi Keuangan.

\section{E. DAFTAR PUSTAKA}


Achmad Tjahjono. (2003). Akuntansi Pengantar Pendekatan Terpadu - Buku

1. Jakarta: PT. Raja Grafindo Persada.

Al. Haryono Jusup. (2003). Dasar-dasar Akuntansi Jilid 1. Yogyakarta:

Sekolah Tinggi Ilmu Ekonomi YKPN.

Bimo Walgito. (2004). Pengantar Psikologi Umum. Yogyakarta: Andi Offset.

Dalyono, M. (2005). Psikologi Pendidikan. Jakarta: PT Rineka Cipta.

Danang Sunyoto. (2007). Analisis Regresi dan Korelasi Bivariat. Yogyakarta: Amara Books.

Darwyan Syah, dkk. (2009). Pengantar Statistika Pendidikan. Jakarta: Gaung Persada Press.

Dimyati dan Mudjiono. (2009). Belajar dan Pembelajaran. Jakarta: PT Rineka Cipta.

Djaali. (2012). Psikologi Pendidikan. Jakarta: Bumi Aksara.

Dyahnita Adiningsih. (2012). Pengaruh Persepsi Siswa tentang Metode Mengajar Guru dan Kemandirian Belajar terhadap Prestasi Belajar Akuntansi Siswa Kelas X Program Keahlian Akuntansi SMK Batik Perbaik Purworejo Tahun Ajaran 2011/2012. Skripsi. Yogyakarta: FE UNY.

Hamzah B. Uno. (2008). Teori Motivasi \& Pengukurannya. Jakarta: PT Bumi Aksara.

Hani Handoko. (2003). Manajemen. Yogyakarta: BPFE.

Ida Cipto Sari (2011). Pengaruh Minat Belajar dan Motivasi Berprestasi terhadap Prestasi Belajar Akuntansi Keuangan Siswa Kelas XI Program Keahlian Akuntansi SMK Muhammadiyah 2 Klaten Utara Tahun Ajaran 2010/2011. Skripsi. Yogyakarta: FE UNY.

King, Laura A. (2010). Psikologi Umum Sebuah Pandangan Apresiatif. Jakarta: Salemba Humanika.

Muhibbin Syah. (2008). Psikologi Pendidikan dengan Pendekatan Baru. Bandung: PT Remaja Rosdakarya.

Nana Sudjana. (2005). Dasar-dasar Proses Belajar Mengajar. Bandung: Sinar Baru Algensindo.

Nana Syaodih Sukmadinata. (2005). Landasan Psikologi Proses Pendidikan. Bandung: PT. Remaja Rosdakarya.

Ngalim Purwanto. (2007). Psikologi Pendidikan. Bandung: PT. Remaja Rosdakarya.

Norma Dwijayati. (2011). Pengaruh Persepsi Siswa tentang Metode Mengajar Guru dan Kebiasaan Belajar terhadap Prestasi Belajar pada Mata Pelajaran Akuntansi Keuangan Siswa Kelas XI Program Keahlian Akuntansi SMK Negeri 1 Depok Tahun Ajaran 2010/2011. Skripsi. Yogyakarta: FE UNY.

Nurlan Darise. (2008). Akuntansi Keuangan Daerah (Akuntansi Sektor Publik). Jakarta: PT Macanan Jaya Cemerlang. 
Oemar Hamalik. (2011). Psikologi Belajar dan Mengajar. Bandung: Sinar Baru Algensindo.

Rudianto. (2009). Pengantar Akuntansi. Jakarta: Erlangga.

Slameto. (2010). Belajar dan Faktor-faktor yang Mempengaruhinya. Jakarta: Rineka Cipta.

Sugihartono. (2007). Psikologi Pendidikan. Yogyakarta: UNY Press.

Sugiyono. (2007). Statistika untuk Penelitian. Bandung: CV Alfabeta.

. (2009). Metode Penelitian Pendidikan. Bandung: CV Alfabeta.

Suharsimi Arikunto. (2009). Dasar-dasar Evaluasi Pendidikan. Jakarta: Bumi Aksara.

. (2010). Prosedur Penelitian Suatu Pendekatan Praktik. Jakarta: Bina Aksara.

Sukardi. (2005). Metode Penelitian Pendidikan. Jakarta: Bumi Aksara.

Sumadi Suryabrata. (2006). Psikologi Pendidikan. Jakrta: PT Raja Grafindo Persada.

Sutratinah Tirtonegoro. (2001). Anak Supernormal dan Program Pendidikannya. Jakarta: PT Bumi Aksara.

Sutrisno Hadi. (2004). Analisis Regresi. Yogyakarta: Andi Offset.

Syaiful Bahri Djamarah. (2010). Strategi Belajar Mengajar. Jakarta: PT Rineka Cipta.

Tohirin. (2008). Psikologi Pembelajaran Pendidikan Agama Islam. Jakarta: PT Raja Grafindo Persada.

Undang-undang Republik Indonesia Nomor 20 Tahun 2003 tentang Sistem Pendidikan Nasional.

Veithzal Rivai. (2007). Kepemimpinan dan Perilaku Organisasi. Jakarta: PT Raja Grafindo Persada.

Wina Sanjaya. (20110). Strategi Pembelajaran Berorientasi Standar Proses Pendidikan. Jakarta: Kencana Prenada Media Group.

Winkel. WS. (2009). Psikologi Pengajaran. Jakarta: PT. Media Abadi.

Zaki Baridwan. (2004). Intermediate Accounting. Yogyakarta: BPFE. 